\title{
An Examination of the Impact of Firm Size and Age on Managerial Disclosure of Intellectual Capital by High-Tech Companies
}

\author{
Blaise M. Sonnier \\ Florida International University • Miami, FL \\ Kerry David Carson \\ University of Louisiana at Lafayette - Lafayette, LA \\ Paula Phillips Carson \\ University of Louisiana at Lafayette • Lafayette, LA
}

\section{Abstract}

A sample of 143 high-technology firms was examined to determine if there were inverse relationships between the size and age of companies and their level of intellectual capital disclosure. Weak inverse relationships were found between number of employees and level of disclosure and between total assets and level of disclosure. There was, however, a significant inverse relationship between firm age and level of disclosure. Multivariate regression provided support that firm age was a significant predictor of level of intellectual capital disclosure. It appears that young companies use increased disclosure to signal to the market their real value and prospects.

\section{Introduction}

In today's knowledge-based economy, a significant source of wealth and competitive advantage is derived from the creation and use of intangible assets and intellectual capital (Canibano, Garcia-Ayuso, \& Sanchez, 2000; Hall, 1992). In 2006 , the World Bank estimated that intangible assets comprise $78 \%$ of worldwide assets and $80 \%$ of assets in high-income countries (World Bank, 2006). The terms "intangible assets" and "intellectual capital" have been used interchangeably and include patents, copyrights, trade secrets, processes, employee know-how, procedures, corporate culture, charismatic leadership, and customer loyalty (Andriessen, 2004; Lev, 2001). Intellectual capital is difficult for other firms to replicate (Barney, 1991; Chakraborty, 1997; Dierickx \& Cool, 1989; Peteraf, 1993) because it is internally generated and has its own unique path to development (Clulow, Gerstman, \& Barry, 2003). Additionally, the legal right to the exclusive use of particular knowledge such as patents, copyrights, and trade secrets make those intangible assets an invaluable resource to the firm (Porter, 1980). 
It is expected that firms with superior intellectual capital will outperform their competitors (McGrath, Tsai, Venkataraman, \& MacMillan, 1996; Wiklund \& Shepherd, 2003). Hope and Hope (1998) concluded that more than half of the value created by a firm in today's economy comes from the management of the firm's intellectual capital rather than physical assets (Guthrie \& Yongvanich, 2004).

The most important assets of a firm in a knowledge-intensive industry are often internally-generated intangible assets which are not reported on the traditional balance sheet under U.S. Generally Accepted Accounting Principles or the International Financial Reporting Standards (Basu \& Waymire, 2008; Canibano et al., 2000; Financial Accounting Standards Board [FASB], 2001a; International Accounting Standards Committee [IASC], 1998). In November, 2006, the CEOs of the world's six largest audit firms released a document in which they stated:

Clearly, a range of 'intangibles' that are not well measured, or not measured at all, under current accounting conventions are driving company performance. Investors and other stakeholders in business information want to know what those intangibles are, and how they might plausibly affect how businesses perform in the future. (DiPiazza, McDonnell, Parrett, Rake, Samyn, \& Turley, 2006, p. 16).

The current financial accounting standards relating to internally-generated intangible assets create numerous challenges for companies operating in knowledge-intensive industries. For example, stock price volatility can result from investors having difficulty in accurately estimating future payoffs and risk (Garcia-Ayuso, 2003). With insiders having more information about intangibles than outsiders, it may increase the risk of insider trading gains (Aboody \& Lev, 2000; Lev, 2001). Still another problem is the increased cost of capital (Botosan, 2006, 1997; Sengupta, 1998; Shi, 2003).

In an effort to overcome or mitigate the challenges caused by current accounting standards, companies may voluntarily disclose information about their intellectual capital (Lundholm \& Van Winkle, 2006). The demand by investors, lenders, and other external stakeholders for information regarding a firm's intellectual capital or intangibles may compel firms to use methods other than the traditional financial statements to supply relevant information about these resources (e.g., Amir \& Lev, 1996; Gelb, 2002; Tasker, 1998). Management may use press releases, electronic and paper promotional literature, and voluntary publications as well as voluntary disclosures in quarterly and annual reports to convey this information (Gelb, 2002).

For new or young firms in the high-technology sector of the economy, the lack of an extensive operating history provides an even greater incentive to disclose 
information regarding their intellectual capital. The objective of such disclosure is to "... close (or narrow) the gap between a company's potential intrinsic market value and its current market value." (Kristandl \& Bontis, 2007, p. 577).

The motivation of firms to voluntarily disclose information is explained by signaling theory. Because insiders know more about a firm than outsiders, there is information asymmetry. When management discloses credible information (sends a signal), it reduces uncertainty for those outside the firm. Thorough and reliable reporting of tangible and intangible assets can improve the firm's reputation, thus allowing it to compete more successfully in raising capital. Managers are motivated to disclose intangible assets if hidden value is high (Wolk, Dodd, \& Rozycki, 2008).

Because the traditional accounting model fails to provide relevant and meaningful information regarding a firm's intellectual capital, voluntary disclosures are often the only way to signal the existence and significance of these resources to investors and lenders. In fact, the primary reason for companies to voluntarily disclose information is to increase the knowledge of investors in order to reduce the cost of capital (Lundholm \& Van Winkle, 2006). While there is debate about whether increased disclosure reduces the cost of capital, most research supports this inverse relationship (Kristandl \& Bontis, 2007; Botosan, 2006). For example, in an examination of the Chinese capital markets, Zhang and Ding (2006) found that as voluntary disclosure increased, the cost of capital decreased. When there exists expanded and credible disclosure, the costs of capital go down, thus allowing firms to pursue positive net present value projects (Khurana, Pereira, \& Martin, 2006).

For small firms that may be unknown or young firms that lack a history of operations, the disclosure of their intellectual capital is essential to attract interest in the firm by investors and financial institutions. Anderson (1966) suggested that smaller firms are seen as higher risk and must pay more for their capital. More recently, Hyytinen and Pajarinen (2007) indicated that the cost of capital is higher for younger firms than for mature firms. In their sample of small businesses, they found that as the firm ages by one year, the cost of capital drops by 1 to 2 basis points.

Several published studies undertook an examination of the impact that firm growth may have on the level of its intellectual capital disclosure in its annual report. Bozzolan, Favotto, and Ricceri (2003), Guthrie, Petty, and Ricceri (2004), and Petty and Cuganesan (2005) each found a statistically significant positive relationship between the size of a firm and its level of intellectual capital disclosure. While 
Bozzolan, Favotto, and Ricceri (2003) used sales as a proxy for size, Guthrie et al. (2004) and Petty and Cuganesan (2005) used market capitalization.

Certain limitations of these three studies warrant mention. First, the sample size of Bozzolan et al. (2003), Guthrie et al. (2004), and Petty and Cuganesan (2005) were relatively small at thirty, fifty, and fifty-three, respectively. Second, each study selected its sample from the largest companies in the respective population. This sample selection was based on the stated assumption that larger companies will have a higher level of disclosure than smaller companies. Each study assumed ". . . that smaller companies will simply play 'follow-the-leader' by benchmarking their disclosure practices against those employed by larger firms" (Guthrie et al., 2004, p. 2). However, as firms grow, managers sequentially change their attention as to which goals are important (Greve, 2008).

The underlying assumption of these previous studies leaves unanswered the question of whether the smaller and younger firms in a given population disclose at higher or lower levels in their annual reports than larger and older firms in the same population. By including firms of all sizes in this study, this limitation of prior studies evaluating the level of intellectual capital disclosure in the annual report of firms is addressed.

Studies have also been conducted evaluating the intellectual capital disclosure of firms in their IPO prospectus (Bukh, Nielsen, Gormsen, \& Mouritsen, 2005; Cordazzo, 2007) and in presentations to financial analysts (Garica-Meca, Parra, Larran, \& Martinez, 2005). None of these studies limited their sample to companies in the high-technology sector of the economy. Furthermore, the index used in these studies measured the number of intellectual capital items disclosed by the firm without regard to the frequency of such disclosure. In this study, the frequency of intellectual capital disclosure was central to the index employed as discussed in detail in the methodology section. Despite the differences in the sample and index used to measure intellectual capital disclosure as compared to this study, these studies are mentioned because they evaluated the relationship between the size and age of the firm on its intellectual capital disclosure, though their findings are inconsistent.

Using market capitalization as a proxy for size, Garica-Meca et al. (2005) found a positive relationship between the size of the firm and the extent of its intellectual capital disclosure. Cordazzo (2007), who analyzed all of the Italian IPO prospectuses from 1999 to $2002(n=86)$, found a positive relationship between a firm's total sales (as a proxy for firm size) and intellectual capital disclosure and also noted a non-significant negative association between age and intellectual capital disclosure. Bukh et al. (2005), who studied all of the Danish IPO prospectuses between 
1990 and $2001(n=68)$, found no relationship between company size (expressed in terms of number of employees) or the age of a firm.

There have been somewhat inconsistent relationships reported between size of the firm and voluntary disclosure (e.g., Bozzolan et al., 2003; Bukh et al., 2005; Guthrie et al., 2004; Haniffa \& Cooke, 2005) and between age of the firm and voluntary disclosure (e.g., Bukh et al., 2005; Cordazzo, 2007; Haniffa \& Cooke, 2002). However, Barnes and Walker (2006) note that younger companies are more dependent upon external funds than more established firms, yet price-earnings, market-tobook, and price-to-sales multiples vary widely among young firms. Therefore, nonfinancial information becomes very important in valuation (Kim \& Ritter, 1999). These less established and typically smaller firms want to reduce uncertainty and raise stakeholder confidence (Haniffa \& Cooke, 2002). Signaling theory suggests that younger and smaller companies will engage in intellectual capital disclosure in an effort to increase valuation and improve investor perceptions. They want to attract investors by signaling to the market their underlying worth. Based on the foregoing, the following hypotheses are suggested.

Hypothesis 1: An inverse relationship exists between the size of companies and their level of intellectual capital disclosure by management.

Hypothesis 2: An inverse relationship exists between the age of companies and their level of intellectual capital disclosure by management.

\section{Methodology}

\section{Sample}

Firms in the high-technology sector of the economy were selected as the subject of this study. While all firms rely on intellectual capital in the operation of their business, high-technology companies rely more heavily on such resources than traditional sector companies. Traditional sector companies rely to a greater extent on physical or fixed assets (such as land, building, machinery, and equipment) to run their business as compared to high-technology firms. Because the assets of traditional sector companies are reflected on their balance sheet, the financial statements of such companies provide investors and others with meaningful information.

In contrast, high-technology firms rely heavily on intellectual capital in the operation of their business and in many cases it is the foundation of their success. Despite the importance of these assets to high-technology companies, the costs of 
internally-generated intangible assets or intellectual capital are immediately writtenoff as expenses and not reflected as assets of the firm. High-technology firms were used in this study given the importance of intangible assets and intellectual capital to their business and the failure of the accounting model to reflect these as assets on their financial statements.

The North American Industry Classification System (NAICS) was used to select high-technology companies. The NAICS industry codes used were 541 (professional, scientific, and technical services), 518 (internet service providers, web search portals, and data processing services), and 516 (internet publishing and broadcasting). The source of data was the Mergent Online ${ }^{\mathrm{TM}}$ database of approximately 10,000 publicly-traded firms in the United States. The 484 high-technology companies (NAICS Code 541, 397 companies; NAICS Code 518, 75 companies; NAICS Code 516, 12 companies) were placed in alphabetical order and assigned numbers based on their order of appearance in the respective alphabetized list.

One hundred fifty companies were selected for inclusion in this study by application of random tables. As further discussed below, to determine the level of intellectual capital disclosure of the sample firms a content analysis was performed on Part I of the fiscal year 2000 and fiscal year 2004 Security and Exchange Commission (SEC) Form 10-K of each firm. A box and whiskers plot generated for the 2000 fiscal year and 2004 fiscal year of the initial 150 companies indicated that seven companies had a level of intellectual capital disclosure that caused them to be outliers in relation to the other companies included in the sample. After elimination of the aforesaid firms, a sample of 143 companies remained in the study.

In 2001, the Financial Accounting Standards Board issued a position paper encouraging firms to voluntarily disclose information about their intangibles and intellectual capital (i.e. FASB, 2001b). Because of the significance of this event, we chose the year before this position paper (fiscal year 2000) and the most recent Form $10-\mathrm{Ks}$ available when collecting the data (fiscal year 2004) as the years for our study. The SEC Form 10-K for each sample firm for the 2000 fiscal year and 2004 fiscal year was downloaded from the Mergent Online ${ }^{\mathrm{TM}}$ database.

\section{Content Analysis}

The level of intellectual capital disclosure of each sample firm for the fiscal years 2000 and 2004 was determined by a content analysis of their annual report for the respective year. Publicly traded firms in the United States are to file annual reports (known as a "Form 10-K") with the Securities and Exchange Commission 
(the "SEC"). The form and content of the Form $10-\mathrm{K}$ is prescribed by the SEC. A content analysis was performed on Part I of the Form 10-K of each firm for the two years studied. Part I is a narrative description of the firm's business and includes, for example, a description of the business, the primary products produced and services provided by the firm, the power of the customer, and the competitive environment of the business. Part I of the Form $10-\mathrm{K}$ is intended to provide meaningful and relevant information to investors, creditors, potential investors, and other external stakeholders. Because the Securities Act of 1934 imposes civil penalties for misrepresentations contained in the Form $10-\mathrm{K}$, this is a reasonably objective source.

Content analysis has been used in a number of studies to measure the intellectual capital disclosure in annual reports (e.g., Abdolmohammadi, 2005; Bontis, 2003; Bozzolan et al., 2003; Brennan, 2001; Goh \& Lim, 2004; Guthrie, Petty, \& Ricceri, 2004; Vergauwen \& Alem, 2005; Williams, 2001). The first step in conducting a content analysis is to compile a list of terms that represent intellectual capital (Bontis, 2003; Brennan, 2001; Vergauwen \& Alem, 2005). In this study, a list of terms was developed for 5 intellectual capital categories which included customer capital, intellectual property, human capital, organizational capital, and supplier capital. The primary list of terms was used by Bontis (2003), Guthrie et al. (2004), and Vergauwen and Alem (2005) in their studies. In addition, the list was expanded to include terms used by Brooking (1996); Edvinsson and Malone (1997); International Federation of Accountants [IFAC] (1998); Ordonez de Pablos (2002); Bozzolan et al. (2003); Guthrie, Boedker, and Cuganesan (2005); and Starovic and Marr (2003). The list of intellectual capital terms was expanded from that used in prior studies to address Vergauwen and Alem's (2005) concern that the low level of intellectual capital disclosure as reported in academic studies may be attributable to a difference in vocabulary used in academia from that used in the corporate world. The final list included 121 terms and phrases. A sample of the terms and phrases is set forth in Table 1.

WordStat, Version 5.0, was used to perform the content analysis. The 10-Ks were downloaded in Microsoft Word format from the Mergent Online ${ }^{\mathrm{TM}}$ database and then directly imported into WordStat for analysis. WordStat generated a report of the number of times that a term or phrase was used in the document. As with other studies (Bontis 2003; Vergauwen \& Alem, 2005), term frequency was used as the measure of the intellectual capital disclosure of that firm for that year. 


\section{Table 1}

\section{Intellectual Capital Disclosure Terms}

\begin{tabular}{|c|c|}
\hline Term & Source \\
\hline Administrative systems & Bozzolan, Favotto, \& Ricceri (2003) \\
\hline Alliances & Guthrie, Boedker, \& Cuganesan (2005) \\
\hline Business collaborations & $\begin{array}{l}\text { Guthrie, Petty, \& Ricceri (2004); Guthrie, Petty, Yongvanich, \& Ricceri (2003); } \\
\text { IFAC (1998) }\end{array}$ \\
\hline Business knowledge & Bontis (2002) \\
\hline Competilive intelligence & Bontis (2002) \\
\hline Corporate culture & $\begin{array}{l}\text { Guthrie, Boedker, \& Cuganesan (2005); Guthrie, Petty, \& Ricceri (2004); } \\
\text { IFAC (1998); Brooking (1996) }\end{array}$ \\
\hline Corporate learning & Bontis (2002) \\
\hline Corporate mission & Starovic \& Marr (2003) \\
\hline Company reputation & Guthrie, Petty, Yongvanich, \& Ricceri (2003); Bontis (2002) \\
\hline Corporate vision & Starovic \& Marr (2003) \\
\hline Customer database & Brooking (1996) \\
\hline Customer tracking & Brooking (1996) \\
\hline Customer turnover & Bozzolan, Favotto, \& Ricceri (2003) \\
\hline Distribution channels & $\begin{array}{l}\text { Guthrie, Boedker, \& Cuganesan (2005); Guthrie, Petty, \& Ricceri (2004); } \\
\text { IFAC (1998); Brooking (1996) }\end{array}$ \\
\hline Employee retention rate & Bozzolan, Favotto, \& Ricceri (2003) \\
\hline Franchising agreements & $\begin{array}{l}\text { Guthrie, Boedker, \& Cuganesan (2005); Guthrie, Petty, \& Ricceri (2004); } \\
\text { IFAC (1998); Brooking (1996) }\end{array}$ \\
\hline Human capital & Bontis (2002) \\
\hline Intellectual property & $\begin{array}{l}\text { Guthrie, Boedker, \& Cuganesan (2005); Guthrie, Petty, \& Ricceri (2004); } \\
\text { Bontis (2002); IFAC (1998) }\end{array}$ \\
\hline Knowledge management & Bontis (2002) \\
\hline Knowledge stock & Bontis (2002) \\
\hline Licensing agreements & $\begin{array}{l}\text { Guthrie, Boedker, \& Cuganesan (2005); Guthrie, Petty, \& Ricceri (2004); } \\
\text { IFAC (1998); Brooking (1996) }\end{array}$ \\
\hline Management philosophy & $\begin{array}{l}\text { Guthrie, Boedker, \& Cuganesan (2005); Guthrie, Petly, \& Ricceri (2004); } \\
\text { IFAC (1998); Brooking (1996) }\end{array}$ \\
\hline Market share & $\begin{array}{l}\text { Guthrie, Petty, Yongvanich, \& Ricceri (2003); } \\
\text { Bozzolan, Favotto, \& Ricceri (2003) }\end{array}$ \\
\hline Organizational capability & Edvinsson \& Malone (1997) \\
\hline $\begin{array}{l}\text { Organizational culture } \\
\text { (company culture) }\end{array}$ & Guthrie, Petty, Yongvanich, \& Ricceri (2003); Bontis (2002) \\
\hline Organizational routines & Starovic \& Marr (2003) \\
\hline Organizational structure & Guthrie, Boedker, \& Cuganesan (2005) \\
\hline Patents & Guthrie, Petty, \& Ricceri (2004); IFAC (1998) \\
\hline Service marks & Guthrie, Petty, Yongvanich, \& Ricceri (2003); IFAC (1998) \\
\hline Staff turnover & Starovic \& Marr (2003) \\
\hline Structural capital & Bontis (2002) \\
\hline Supplier knowledge & Bontis (2002) \\
\hline Supplier relations & Guthrie, Boedker, \& Cuganesan (2005) \\
\hline Trademark & Guthrie, Petty, Yongvanich, \& Ricceri (2003); IFAC (1998) \\
\hline Trade secrets & Guthrie, Petty, Yongvanich, \& Ricceri (2003); IFAC (1998) \\
\hline
\end{tabular}




\section{Results}

Table 2 presents descriptive statistics of the 143 companies included in the study. The mean (median) number of employees of the firms included in the sample were 4,206.79 (704) and 4,606.49 (798) in 2000 and 2004, respectively. The 72 sample firms with the smallest number of employees had a mean (median) number of employees of 305.49 (290) and 320.36 (285.50) in 2000 and 2004, respectively. The 71 sample firms with the largest number of employees had a mean (median) number of employees of 8,219.56 (2,037.50) and 8,952.99 (2,533) in 2000 and 2004. The mean (median) of total assets and total revenue in 2000 of the sample firms was $\$ 752$ million (\$182.4 million) and \$626 million (\$118.8 million), respectively. The 72 sample firms with the smallest amount of total assets and total revenue, respectively, had a mean (median) of $\$ 77.5$ million ( $\$ 57.6$ million) and $\$ 43$ million ( $\$ 37.8$ million) in 2000. In 2000, the 71 sample firms with the largest amount of total assets and total revenue had a mean (median) of $\$ 1.436$ billion ( $\$ 365$ million) and $\$ 1.226$ billion ( $\$ 398.8$ million). The mean (median) of total assets and total revenue in 2004 of the sample firms was $\$ 1.068$ billion ( $\$ 182.7$ million) and $\$ 823.6$ million ( $\$ 143.5$ million), respectively. The 72 sample firms with the smallest amount of total assets and total revenue had a mean (median) of $\$ 82.4$ million ( $\$ 77.8$ million) and $\$ 65.9$ million ( $\$ 68.1$ million) in 2004. In 2004, the 71 sample firms with the largest amount of total assets and total revenue had a mean (median) of $\$ 2.067$ billion ( $\$ 602.5$ million) and $\$ 1.592$ billion ( $\$ 520.7$ million).

Table 3 presents descriptive statistics regarding the level of intellectual capital disclosure of the firms in our sample in fiscal year 2000 and 2004. As discussed above, the number of times that a firm used a term or phrase related to the intellectual capital construct in its annual report is used as a measure of the firm's level of intellectual capital disclosure in this study. The mean (median) number of times that a firm in our sample made an intellectual capital disclosure in its annual report was 44.44 (40) and 43.97 (40) times in 2000 and 2004, respectively.

As set forth in Table 3, a univariate analysis of the level of intellectual capital disclosure by the smallest one-half and the largest one-half of the firms in the sample measured by total assets and total revenue, respectively, reveals that there is not a statistically significant difference in the level of such disclosure between them either in 2000 and 2004. While the smallest one-half of the firms measured by number of employees had a statistically significant higher level of intellectual capital disclosure in fiscal year 2000 than the largest one-half of the firms $(t=1.97, p=.03)$, there was not a statistically significant difference in the level of disclosure of the smallest and 
largest one-half of the firms measured by number of employees in the sample in fiscal year $2004(t=1.3604, p=.09)$. The univariate analysis of the size variables used in this study does not support Hypothesis 1.

Table 2

Descriptive Statistics of Companies

\begin{tabular}{|c|c|c|c|c|c|c|}
\hline & \multicolumn{3}{|c|}{ Fiscal Year 2000} & \multicolumn{3}{|c|}{ Fiscal Year 2004} \\
\hline & $\begin{array}{l}\text { All Firms } \\
(n=143)\end{array}$ & $\begin{array}{l}\text { Lower } \\
\text { One-Half } \\
(n=72)\end{array}$ & $\begin{array}{c}\text { Upper } \\
\text { One-Half } \\
(n=71)\end{array}$ & $\begin{array}{l}\text { All Firms } \\
(n=143)\end{array}$ & $\begin{array}{c}\text { Lower } \\
\text { One-Half } \\
(n=72)\end{array}$ & $\begin{array}{c}\text { Upper } \\
\text { One-Half } \\
(n=71)\end{array}$ \\
\hline \multicolumn{7}{|c|}{ No. of Employees: } \\
\hline Mean & $4,206.79$ & 305.49 & $8,219.56$ & $4,606.49$ & 320.36 & $8,952.99$ \\
\hline Median & 704.00 & 290.00 & $2,037.50$ & 798.00 & 285.50 & $2,533.00$ \\
\hline St. Dev. & $13,352.48$ & 192.61 & $18,222.89$ & $13,933.84$ & 219.59 & $18,861.19$ \\
\hline \multicolumn{7}{|l|}{ Age: } \\
\hline Mean & 15.13 & 6.69 & 23.69 & 19.13 & 10.69 & 27.69 \\
\hline Median & 9.00 & 7.00 & 19.00 & 13.00 & 11.00 & 23.00 \\
\hline St. Dev. & 12.82 & 1.56 & 13.53 & 12.82 & 1.56 & 13.53 \\
\hline \multicolumn{7}{|c|}{$\begin{array}{l}\text { Total Assets: } \\
\text { (in thousands of dollars) }\end{array}$} \\
\hline Mean & 752,050 & 77,509 & $1,436,091$ & $1,068,001$ & 82,451 & $2,067,433$ \\
\hline Median & 182,396 & 57,551 & 365,284 & 182,743 & 77,769 & 602,502 \\
\hline St. Dev. & $2,069,184$ & 53,642 & $2,782,060$ & $3,015,296$ & 49,522 & $4,053,284$ \\
\hline \multicolumn{7}{|c|}{$\begin{array}{l}\text { Total Revenue: } \\
\text { (in thousands of dollars) }\end{array}$} \\
\hline Mean & 626,006 & 42,990 & $1,225,680$ & 823,597 & 65,917 & $1,591,949$ \\
\hline Median & 118,809 & 37,793 & 398,754 & 143,547 & 68,061 & 520,669 \\
\hline St. Dev. & $2,091,229$ & 33,720 & $2,866,346$ & $2,497,865$ & 43,687 & $3,386,105$ \\
\hline
\end{tabular}

A univariate analysis of the level of intellectual capital disclosure by younger versus older firms supports Hypothesis 2. In fiscal year 2000, the youngest one-half of the sample firms had a mean (median) level of intellectual capital disclosure of 53.22 (48) as compared to 35.54 (30) of the oldest one-half of the sample firms. The difference in the level of intellectual capital disclosure was statistically significant $(t=4.0930, p<.0001)$. The results are consistent in 2004 where the youngest onehalf of the sample firms had a mean (median) level of intellectual capital disclosure of 49.33 (46.50), as compared to 38.52 (33) of the oldest one-half of the sample firms. Again, the difference in the level of intellectual capital disclosure between the youngest one-half and oldest one-half of the sample firms was statistically significant $(\mathrm{t}=2.6341, \mathrm{p}=.005)$. 
Table 3

Descriptive Statistics of Intellectual Capital Disclosure

\begin{tabular}{ccccc}
\hline \multicolumn{2}{c}{ Fiscal Year 2000 } & \multicolumn{2}{c}{ Fiscal Year 2004 } \\
\hline Lower & Upper & Lower & Upper \\
One-Half & $\begin{array}{c}\text { One-Half } \\
(n=72)\end{array}$ & $\begin{array}{c}\text { One-Half } \\
(n=71)\end{array}$ & $\begin{array}{c}\text { One-Half } \\
(n=72)\end{array}$ & $(n=71)$ \\
\hline
\end{tabular}

No. of Employees:a

Mean

Median

St. Dev.

\section{Age: ${ }^{b}$}

Mean

Median

St. Dev.

$\begin{array}{ll}48.85 & 39.97 \\ 45.00 & 33.00 \\ 28.38 & 25.42\end{array}$

53.22

48.00

26.69

$$
\begin{aligned}
& 35.54 \\
& 30.00 \\
& 24.92
\end{aligned}
$$

46.78

44.00

41.11

26.35

34.00

23.39

49.33

46.50

38.52

33.00

25.50

23.42

\section{Total Assets: ${ }^{c}$}

Mean

Median

43.64

39.00

45.25

43.00

46.26

41.63

27.93

26.66

43.00

37.00

26.79

22.99

Total Revenue:d

Mean

46.99

41.00

41.86

38.00

47.04

40.85

Median

28.39

25.94

37.00

St. Dev.

28.39
a The difference in the level of intellectual capital disclosure between the smallest and largest one-half of sample firms measured by number of employees was statistically significant in $2000(t=1.97, p=.03)$. The difference was not statistically significant in $2004(\mathrm{t}=1.3604, \mathrm{p}=.09)$.

${ }^{b}$ There was a statistically significant difference in the level of intellectual capital disclosure between the youngest versus oldest one-half of the sample firms in fiscal year $2000 \mathrm{l} t=$ $4.0930, p<.0001)$ and in fiscal year $2004(t=2.6341, p=.005)$.

c There was not a statistically significant difference in the level of intellectual capital disclosure between the smallest and largest one-half of the sample firms measured by total assets in fiscal year $2000(t=.3525, p=.36)$ and fiscal year $2004(t=4.177, p=.13)$.

d There was not a statistically significant difference in the level of intellectual capital disclosure between the smallest and iargest one-half of the sample firms measured by total revenue in fiscal year $2000(t=1.1276, p=.13)$ and fiscal year $2004(t=1.4868, p=.07)$.

\section{Hypothesis 1}

Hypothesis 1 predicts that an inverse relationship exists between the size metrics of a high-technology company and its level of intellectual capital disclosure. Total assets, total revenue, and number of employees were used as proxies for the 
size of the firm. Total assets, total revenue, and number of employees are often used in the business literature as a proxy for firm size (e.g., Carcello \& Nagy, 2004; Geiger \& Raghunanda, 2002; Huang, Mishra, \& Raghunanda, 2007; Tang, 2008). The Pearson's $r$ correlation coefficient was used to test the relationship between the size and value metrics and level of intellectual capital disclosure. However, it should be recognized that while correlations are informative, they have limitations. A correlation is a simple statistic that describes the relationship between two variables. There are no controls over additional factors. Therefore, while we offer correlation results, we follow up with regression analysis.

For the fiscal year 2000 , the data supported a finding of a statistically significant inverse relationship between the level of intellectual capital disclosure and total assets $[\mathrm{r}=-.1414, \mathrm{p}=.046, \mathrm{n}=143]$, total revenue $[\mathrm{r}=-.1575, \mathrm{p}=.031, \mathrm{n}=142]$, and number of employees $[\mathrm{r}=-.1768, \mathrm{p}=.018, \mathrm{n}=142]$. Likewise, for fiscal year 2004 the data supported a statistically significant inverse relationship between the level of intellectual capital disclosure and total assets $[r=-.1387, p=.049, n=143]$ and number of employees $[r=-.1699, p=.021, n=143]$. A marginally significant inverse relationship was shown to exist between the level of intellectual capital disclosure and total revenue for the 2004 fiscal year $[r=-.1356, p=.053, n=143]$. The practical effect of the inverse relationship between the level of intellectual capital disclosure and each variable evaluated in Hypothesis 1 is diminished by the $95 \%$ confidence interval for each combination which approached a finding of no correlation. Likewise, as established by the multi-regression analyses below, none of the variables evaluated in Hypothesis 1 contribute to the prediction of the level of disclosure of intellectual capital by high-technology companies. Accordingly, while the data supports Hypothesis 1, the practical effect of that finding is limited.

\section{Hypothesis 2}

Hypothesis 2 predicts an inverse relationship between the age of a high-technology company and its level of intellectual capital disclosure. The age of the firm was based on the year of its formation. For both the $2000[r=-.3271, p=.000,95 \%$ $\mathrm{Cl}=-.420$ to $-.227, \mathrm{n}=143]$ and $2004[\mathrm{r}=-.2979, \mathrm{p}=.000,95 \% \mathrm{CI}=-.393$ to -.196 , $\mathrm{n}=143]$ fiscal year, a significant inverse relationship existed between the age and the level of intellectual capital disclosure by a high-technology firm. In addition, the Pearson's $r$ coefficient and the $95 \%$ confidence interval establishes that the relationship is strong to medium. Given the foregoing, Hypothesis 2 is supported. 


\section{Multiple Regression Analysis}

Of the four variables evaluated in the hypotheses, age was the variable that had the greatest practical effect on the level of intellectual capital disclosure as demonstrated by the Pearson's $r$ coefficient and the 95\% confidence interval. Accordingly, age is the foundation of the multivariable regression formulas of the size/ metrics variables evaluated in this study. The correlation matrixes for the 2000 fiscal year and the 2004 fiscal year are displayed in Table 4 and Table 5, respectively, for the age, number of employees, total assets, total revenue, and level of intellectual capital disclosure variables evaluated in this study.

Table 4

Correlation Matrix (2000)

\begin{tabular}{|c|c|c|c|c|}
\hline & E00 & TADO & TR00 & AGEOO \\
\hline TADO & $\begin{array}{c}r=.8103 \\
n=142 \\
p=.01 \\
{[.7695 \text { to } .8445]}\end{array}$ & & & \\
\hline TROO & $\begin{array}{c}r=.9773 \\
n=141 \\
p=.01 \\
{[.9719 \text { to } .9817]}\end{array}$ & $\begin{array}{c}r=.7842 \\
n=142 \\
p=.01 \\
{[.7386 \text { to } .8226]}\end{array}$ & & \\
\hline AGE00 & $\begin{array}{c}r=.1179 \\
\mathrm{n}=142 \\
p=.09 \\
{[.0098 \text { to } .2234]}\end{array}$ & $\begin{array}{c}r=.1425 \\
n=143 \\
p=.05 \\
{[.0351 \text { to } .2466]}\end{array}$ & $\begin{array}{c}r=.1031 \\
\mathrm{n}=142 \\
p=.11 \\
{[-.005 \text { to } .2091]}\end{array}$ & \\
\hline ICDOO & $\begin{array}{c}r=-.1768 \\
\mathrm{n}=142 \\
p=.02 \\
{[-.280 \text { to }-.070]}\end{array}$ & $\begin{array}{c}r=-.1414 \\
n=143 \\
p=.05 \\
{[-.246 \text { to }-.034]}\end{array}$ & $\begin{array}{c}r=-.1575 \\
n=142 \\
p=.03 \\
{[-.261 \text { to }-.050]}\end{array}$ & $\begin{array}{c}r=-.3271 \\
\mathrm{n}=143 \\
p=.01 \\
{[-.420 \text { to }-.227]}\end{array}$ \\
\hline
\end{tabular}

${ }^{*} 95 \%$ confidence intervals are in brackets

Notes:

$\mathrm{E}=$ number of employees

$\mathrm{TA}=$ total assets

$T R=$ total revenue

$A G E=$ age of the firm

$I C D=$ intellectual capital disclosure 
Table 5

Correlation Matrix (2004)

\begin{tabular}{|c|c|c|c|c|}
\hline & E04 & TA04 & TR04 & AGE04 \\
\hline TA04 & $\begin{array}{c}r=.8434 \\
n=143 \\
p=.01 \\
{[.8092 \text { to } .8720]}\end{array}$ & & & \\
\hline TR04 & $\begin{array}{c}r=.9772 \\
n=143 \\
p=.01 \\
{[.9717 \text { to } .9816]}\end{array}$ & $\begin{array}{c}r=.8568 \\
n=143 \\
p=.01 \\
{[.8252 \text { to } .8831]}\end{array}$ & & \\
\hline AGE04 & $\begin{array}{c}r=.1445 \\
n=143 \\
p=.04 \\
{[.0372 \text { to } .2486]}\end{array}$ & $\begin{array}{c}r=.1578 \\
\mathrm{n}=143 \\
p=.03 \\
{[.0508 \text { to } .2612]}\end{array}$ & $\begin{array}{c}r=.1333 \\
n=143 \\
p=.06 \\
{[.0258 \text { to } .2378]}\end{array}$ & \\
\hline ICD04 & $\begin{array}{c}r=-.1699 \\
n=143 \\
p=.02 \\
{[-.273 \text { to }-.063]}\end{array}$ & $\begin{array}{c}r=-.1387 \\
n=143 \\
p=.05 \\
{[-.243 \text { to }-.031]}\end{array}$ & $\begin{array}{c}r=-.1356 \\
n=143 \\
p=.05 \\
{[-.240 \text { to }-.028]}\end{array}$ & $\begin{array}{c}r=-.2979 \\
\mathrm{n}=143 \\
p=.01 \\
{[-.393 \text { to }-.196]}\end{array}$ \\
\hline
\end{tabular}

${ }^{\star} 95 \%$ confidence intervals are in brackets.

Notes:

$\mathrm{E}=$ number of employees

$T A=$ total assets

$\mathrm{TR}=$ total revenue

$A G E=$ age of the firm

$I C D=$ intellectual capital disclosure

As demonstrated by Table 4 and Table 5, there is a high degree of correlation among number of employees, total assets, and total revenue (2000 fiscal year: .7842 to .9773 and 2004 fiscal year: .8434 to .9772 ). This prohibited the use of all variables in a single regression formula due to multicollinearity. To address the issue of multicollinearity, separate formulas were evaluated that included age as one predictor of intellectual capital disclosure and either number of employees (EMPL), total assets (TA), or total revenue (TR) as the second predictor. These formulas were evaluated for both fiscal year 2000 and fiscal year 2004. The following are the multivariate regression formulas evaluated in this study using the method of entering all variables simultaneously. The level of intellectual capital disclosure is the dependant variable for each of the formulas below. 


$$
\begin{aligned}
& I C D_{2000}=B_{2000}+A G E_{2000} X_{2000}+E M P L_{2000} X_{2000}+\hat{e}_{i} \\
& I C D_{2004}=B_{2004}+A G E_{2004} X_{2004}+E M P L_{2004} X_{2004}+\hat{e}_{i} \\
& I C D_{2000}=B_{2000}+A G E_{2000} X_{2000}+T A_{2000} X_{2000}+\hat{e}_{i} \\
& I C D_{2004}=B_{2004}+A G E_{2004} X_{2004}+T A_{2004} X_{2004}+\hat{e}_{i} \\
& I C D_{2000}=B_{2000}+A G E_{2000} X_{2000}+T R_{2000} X_{2000}+\hat{e}_{i} \\
& I C D_{2004}=B_{2004}+A G E_{2004} X_{2004}+T R_{2004} X_{2004}+\hat{e}_{i}
\end{aligned}
$$

Each equation significantly predicted the level of intellectual capital disclosure at $p \leq .05$. The adjusted $R^{2}$ of the equations ranged from $8.45 \%$ to $12.00 \%$. The firm's age was the only predictor that reached a level of significance at $\mathrm{p} \leq .05$ and it did so in each equation. As predicted in Hypothesis 2, Equations (1) through (6) establish a statistically significant inverse relationship between the age of a firm and its level of intellectual capital disclosure for fiscal year 2000 and fiscal year 2004. No other variable was a statistically significant predictor of the level of intellectual capital disclosure. Table 6 is a summary of the results of each model represented by Equations (1) through (6) above. The sample size in the regression analysis is slightly smaller than the original sample because the statistical technique eliminated cases with missing data.

In order to test whether there was a nonlinear relationship between the age variable and the rate of intellectual capital disclosure, quadratic functions were created by adding age squared as a variable to equations (1) through (6). None of the quadratic equations led to a significant improvement of the $R^{2}$ as compared to the $R^{2}$ of the original equations.

Based on the findings of each hypothesis and the multivariate analysis of the size variables above, it appears that age was the only variable that has a practical effect on the level of intellectual capital disclosure of high-technology companies. 


\section{Table 6}

\section{Results Multivariate Regression Formulas}

$\begin{array}{lcccccc}\text { Equation (1) } I C D_{2000}= & B_{2000}+A G E_{2000} X_{2000}+E M P L_{2000} X_{2000}+\hat{e}_{i} \\ \text { No. of } \\ \text { Intercept }\end{array}$

Equation (2) $\quad I C D_{2004}=B_{2004}+A G E_{2004} X_{2004}+E M P L_{2004} X_{2004}+\hat{e}_{i}$

No. of

\begin{tabular}{lcccccc} 
Intercept & Age & Employees & Adjusted $R^{2}$ & F-Stat & $P$ & $n$ \\
\hline 53.276 & -.545 & -.0002 & $9.24 \%$ & 8.227 & .01 & 140 \\
& $t=3.455$ & $t=1.604$ & & & & \\
& $p=.01$ & $p=.1110$ & & & & \\
& & & &
\end{tabular}

Equation (3) $\quad I C D_{2000}=B_{2000}+A G E_{2000} X_{2000}+T A_{2000} X_{2000}+\hat{e}_{i}$

Total

\begin{tabular}{lcccccc} 
Intercept & Age & Assets & Adjusted R & F-Stat & $\mathrm{P}$ & $n$ \\
\hline 55.469 & -.666 & -1.273 & $10.35 \%$ & 9.199 & .01 & 140 \\
& $t=3.903$ & $t=1.206$ & & & & \\
$p=.01$ & $p=.2300$ & & & &
\end{tabular}

Equation (4) $\quad I C D_{2004}=B_{2004}+A G E_{2004} X_{2004}+T A_{2004} X_{2004}+\hat{e}_{i}$

Total

\begin{tabular}{lcccccc} 
Intercept & Age & Assets & Adjusted R & F-Stat & P & $n$ \\
\hline 53.153 & -.552 & -7.798 & $8.45 \%$ & 7.551 & .01 & 140 \\
$t=3.481$ & $\begin{array}{c}t=1.157 \\
p=.01\end{array}$ & & & & & \\
& $p=.2493$ & & & &
\end{tabular}

\begin{tabular}{|c|c|c|c|c|c|c|}
\hline Equation (5) & $1 C D_{2000}=B_{2000}+$ & $\begin{array}{c}E_{2000} X_{2000}+ \\
\text { Total }\end{array}$ & $R_{2000} X_{2000}+\hat{e}$ & & & \\
\hline Intercept & Age & Revenue & Adjusted $R^{2}$ & F-Stat & $P$ & $n$ \\
\hline 55.634 & $\begin{array}{c}-.670 \\
t=3.937 \\
p=.01\end{array}$ & $\begin{array}{c}-1.635 \\
t=1.566 \\
p=.1195\end{array}$ & $11.00 \%$ & 9.717 & .01 & 139 \\
\hline
\end{tabular}

Equation (6) $\quad I C D_{2004}=B_{2004}+A G E_{2004} X_{2004}+T R_{2004} X_{2004}+\hat{e}_{i}$

Total

\begin{tabular}{lcccccc} 
Intercept & Age & Revenue & Adjusted R & F-Stat & P & $n$ \\
\hline 53.178 & -.556 & -9.770 & $8.52 \%$ & 7.614 & .01 & 140 \\
& $t=3.518$ & $t=1.205$ & & & & \\
& $p=.01$ & $p=.2300$ & & & & \\
& & & & & &
\end{tabular}




\section{Conclusion}

Hypothesis 1 predicted an inverse relationship between the size metrics of companies and their level of intellectual capital. The metrics evaluated in connection with Hypothesis 1 were total assets, total revenue, and number of employees. Although a significant inverse relationship was demonstrated between each of these variables and the level of intellectual capital disclosure by high-technology companies, the practical effect and size of such inverse relationship were minimal in light of the Pearson's $r$ correlation and the $95 \%$ confidence interval for said variables. Additionally, neither the total assets, the total revenue, nor the number of employees of the company were predictive of the level of intellectual capital disclosure. A study of the relationship of the level of intellectual capital disclosure by companies and their number of employees, total assets and total revenue by industry group (i.e. computer software firms, professional service firms, and biotechnology firms) within the broader high-technology company category may provide additional explanations regarding firm characteristics that impact the level of intellectual capital disclosure.

In support of Hypothesis 2, an inverse relationship between the age of the company and its level of intellectual capital disclosure was shown to exist by this research data. The practical effect and size of the influence of age on the level of intellectual capital disclosure was shown by the data to be sizable. The multi-regression analyses performed in connection with the hypotheses variables confirmed that age was a predictor of the level of the company's intellectual capital disclosure. Of the variables examined in the study, the age of a firm was the single most influential factor on the level of disclosure of intellectual capital by companies. No prior study in the intellectual capital literature has examined the relationship between the level of intellectual capital disclosure and the age of firms in the high-technology sector of the economy in their annual report.

While there are significant findings in this research, it should be noted that there are limitations with using of fixed list of terms in performing content analysis of a document. First, the words used by firms in communications to its stakeholders or potential stakeholders may be different to some degree than those used in the academic community. Second, the context in which a word, term or phrase is used may have a different meaning than that contemplated when included on the list of words or phrases to denote intellectual capital. Third, the methodology employed in this study assumed frequency of words as an indicator of the importance or intellectual capital to the firm without qualitatively evaluating the use of the term or phrase. 
Some studies in the intellectual capital field have used a disclosure index that is a ratio of the number of intellectual capital indicators disclosed by the firm to the total number of indicators in the intellectual capital framework employed in the respective study (Bukh et al., 2005; Cordazzo, 2007; Garcia-Meca, Parra, Larran, \& Martinez, 2005). If an item is disclosed by the firm, it is counted once in determining the disclosure index for the firm regardless of the number of times that a disclosure is made about the item. This index measures the extent or depth of a firm's disclosure of the intellectual capital construct employed by the applicable study. However, because this study is designed to compare the level of intellectual capital disclosure among firms in the high-technology sector of the economy and the relationship of the frequency of disclosure with age and size of the firm, the index used to measure the level of a firm's intellectual capital disclosure is based on the frequency of the use of predefined terms or phrases that represent the intellectual capital construct. Despite some limitations in this research, the results of the study suggest that younger companies will disclose their intellectual capital at higher levels in order to compensate for their lack of operating history and the inability of the traditional accounting model to support quantification of the expenditures as the creation of an asset on the balance sheet for the firm's investment in intellectual capital resources. From a practical standpoint, managers can use the findings of this study when deciding to disclose the organization's intellectual capital. For example, when the firm is young, executives may want to strategically reveal information in order to reduce the cost of capital. Startup firms disclose their intellectual capital at higher levels than mature firms to present a better image to external stakeholders. Lacking operating history, younger firms are likely to use disclosure to compensate for limitations of the traditional accounting model. This disclosure is essential for young firms to reduce their cost of capital. However, as the firm ages and grows, top management may want to be less forthcoming with information in order to conceal the intellectual capital which affords them a competitive advantage.

Age appears to be an important factor in explaining the level of intellectual disclosure. However, because it only explains about $10 \%$ of the variance, there are likely numerous other factors involved which include stock volatility, the nature of the ownership structure, and share concentration as well as others (e.g., Almazan, Harzell, \& Starks, 2005; Botosan \& Plumlee, 2002; Bushee \& Noe, 2000; Cormier, Magnan, \& Van Veithoven, 2005). This research leaves other unanswered questions regarding the relationship between the age of the firm and the level of intellectual capital disclosure. For example, its needs to be determined in which sectors of the economy this relationship exists or not. Further, it would be interesting to examine 
the level of management's intellectual disclosure through the latter phases of the organizational life cycle (maturity/decline and death). It seems plausible that when companies attempt to turn the decline phase into a renewal phase, there would be an increase in attention to investment in intellectual capital (e.g., the retraining of employees). As suggested in this study, young firms disclose their intellectual capital, but as they grow, they reveal less because they do not want to lose competitive advantage. In the renewal phase, however, it may be important for top management to convince external stakeholders about their investment in intellectual capital by increasing their level of disclosure.

\section{References}

Abdolmohammadi, M. (2005). Intellectual capital disclosure and market capitalization. Journal of Intellectual Capital, 6(3), 397-416.

Aboody, D., \& Lev, B. (2000). Information asymmetry, R\&D, and insider gains. Journal of Finance, 55(6), 2747-2766.

Almazan, A., Hartzell, J. C., \& Starks, L. T. (2005). Active institutional shareholders and costs of monitoring: Evidence from executive compensation. Financial Management, 34(4), 5-34.

Amir, E., \& Lev, B. (1996). Value-relevance of nonfinancial information: The wireless telecommunications industry. Journal of Accounting and Economics, 22 (1-3), 3-30.

Anderson, L. P. (1966). The influence of developments: The capital markets on fund acquisition by the firm. Journal of Financial \& Quantitative Analysis, 1(4), 98-100.

Andriessen, D. (2004). Making sense of intellectual capital. Oxford: Elsevier.

Barnes, E., \& Walker, M. (2006). The seasoned-equity issues of UK firms: Market reaction and issuance method choice. Journal Business Finance \& Accounting, $33(1 / 2), 45-78$.

Barney, J. (1991). Firm resources and sustained competitive advantage. Journal of Management, 17(1), 99-120.

Basu, S., \& Waymire, G. (2008). Has the importance of intangibles really grown? And if so, why? Accounting and Business Research, 38(3), 171-190.

Bontis, N. (2003). Intellectual capital disclosure in Canadian corporations. Journal of Human Resource Costing \& Accounting, 3(1/2), 41-60.

Botosan, C. (1997). Disclosure level and the cost of equity capital. Accounting Review, 72(3), 323-349. 
Botosan, C. A. (2006). Disclosure and the cost of capital: What do we know? Accounting and Business Research, 36(3), 31-40.

Botosan, C. A., \& Plumlee, M. A. (2002). A re-examination of disclosure level and the expected cost of equity capital. Journal of Accounting Research, 40(1), 21-40.

Bozzolan, S., Favotto, F., \& Ricceri, F. (2003). Italian annual intellectual capital disclosure: An empirical analysis. Journal of Intellectual Capital, 4(4), 543-558.

Brennan, N. (2001). Reporting intellectual capital in annual reports: Evidence from Ireland? Journal of Intellectual Capital, 14(4), 423-436.

Brooking, A. (1996). Intellectual capital: Core assets for the third millennium enterprise. London: Thomson Business Press.

Bukh, P. N., Nielsen, C., Gormsen, P., \& Mouritsen, J. (2005). Disclosure of information on intellectual capital in Danish IPO prospectuses. Accounting, Auditing \& Accountability Journal, 18(6), 713-732.

Bushee, B. J., \& Noe, C. F. (2000). Corporate disclosure practices, institutional investors, and stock return volatility. Journal of Accounting Research, 38(3), 171-202.

Canibano, L., Garcia-Ayuso, M., \& Sanchez, P. (2000). Accounting for intangibles: A literature review. Journal of Accounting Literature, 19, 102-130.

Carcello, J. V., \& Nagy, A. L. (2004). Audit firm tenure and fraudulent financial reporting. Auditing: A Journal of Practice and Theory, 23(2), 55-69.

Chakraborty, K. (1997). Sustained competitive advantage: A resource-based framework. Advances in Competitiveness Research, 5(1), 32-63.

Clulow, V., Gerstman, J., \& Barry, C. (2003). The resource-based view and sustainable competitive advantage: The case of a financial services firm. Journal of European Industrial Training, 27(5), 220-232.

Cordazzo, M. (2007). Intangibles and Italian IP prospectuses: A disclosure analysis. Journal of Intellectual Capital, 8(2), 288-305.

Cormier, D., Magnan, M., \& Van Veithoven, B. (2005). Environmental disclosure quality in large German companies: Economic incentives, public pressures or institutional conditions? European Accounting Review, I4(1), 3-39.

DiPiazza, S. A., McDonnell, D., Parrett, W. G., Rake, M. D., Samyn, F., \& Turley, J. S. (2006). Global capital markets and the global economy: A vision from the CEOs of international audit networks. Retrieved June 15, 2009, from www.globalpublicpolicysymposium.com/CEO_Vision.pdf

Dierickx, I., \& Cool, K. (1989). Asset stock accumulation and sustainability of competitive advantage. Management Science, 35(12), 1504-1511. 
Edvinsson, L., \& Malone, M. S. (1997). Intellectual capital: Realizing your company's true value by finding its hidden brainpower. New York: Harper Collins.

Financial Accounting Standards Board (2001a). Goodwill and intangible assets. Statement of Financial Accounting Standards No. 142. Norwalk, CT: FASB.

Financial Accounting Standards Board (2001b). Improving business reporting: Insights into enhancing voluntary disclosures. Business reporting research project. Norwalk, CT: FASB.

Garcia-Ayuso, M. (2003). Factors explaining the inefficient valuation of intangibles. Accounting, Auditing \& Accountability Journal, 16(1), 57-69.

Garcia-Meca, E., Parra, I., Larran, M., \& Martinez, I. (2005). The explanatory factors of intellectual capital disclosure to financial analysts. European Accounting Review, 14(1), 63-94.

Geiger, M. A., \& Raghunandan, K. (2002). Audit tenure and audit reporting failures. Auditing, 21(1), 67-78.

Gelb, D. (2002). Intangible assets and firms' disclosure: An empirical investigation. Journal of Business Finance \& Accounting, 29(3/4), 57-476.

Goh, P., \& Lim, K. P. (2004). Disclosing intellectual capital in company annual reports: Evidence from Malaysi. Journal of Intellectual Capital, 5(3), 500-510.

Greve, H. R. (2008). The behavioral theory of firm growth: Sequential attention to size and performance goals. Academy of Management Journal, 51(3), 470-494.

Guthrie, J., Boedker, C., \& Cuganesan, S. (2005). The strategic significance of intellectual capital information in annual reporting. Working paper. Macquarie Graduate School of Management, Sydney.

Guthrie, J., Petty, R. M., \& Ricceri, F. (2004). External intellectual capital reporting: Contemporary evidence from Hong Kong and Australia. Working paper. Macquarie Graduate School of Management, Sydney.

Guthrie, J., \& Yongvanich, K. (2004). Intellectual capital reporting: Comparsion of various frameworks. Working paper. Macquarie Graduate School of Management, Sydney.

Hall, R. (1992). The strategic analysis of intangible resources. Strategic Management Journal, 13(2), 135-144.

Haniffa, R. M., \& Cooke, T. E. (2002). Culture, corporate governance and disclosure in Malaysian corporations. ABACUS, 38(3), 317-349.

Haniffa, R. M., \& Cooke, T. E. (2005). The impact of culture and governance on corporate social reporting. Journal of Accounting \& Public Policy, 24(5), 391-430.

Hope, J., \& Hope, T. (1998). Competing in the third wave: The ten key management issues of the information age. Boston: Harvard Business School Press. 
Huang, H., Mishra, S., \& Raghunandan, K. (2007). Types of nonaudit fees and financial reporting quality. Auditing: A Journal of Practice and Theory, 26(1), 133-145.

Hyytinen, A., \& Pajarinen, M. (2007). Is the cost of debt capital higher for younger firms? Scottish Journal of Political Economy, 54(1), 55-71.

International Accounting Standards Committee (1998). International Accounting Standard No. 38: Accounting for intangibles. London: IASC

International Federation of Accountants (1998). The measurement and management of intellectual capital: An introduction. New York.

Khurana, I., Pereira, K. R., \& Martin, X. (2006). Firm growth and disclosure: An empirical analysis. Journal of Financial and Quanitative Analysis, 4l(2), 357-380.

Kim, M., \& Ritter, J. R. (1999). Valuing IPOs. Journal of Financial Economics, 53(3), 409-437.

Kristandl, G., \& Bontis, N. (2007). Constructing a definition for intangibles using the resource based view of the firm. Management Decision, 45(9), 1510-1524.

Lev, B. (2001). Intangibles: Management, measurement and reporting. The Brookings Institution.

Lundholm, R., \& Van Winkle, M. (2006). Motives for disclosure and non-disclosure: A framework and review of the evidence. Accounting \& Business Research, 36(3), 43-48.

McGrath, R.G., Tsai, M., Venkataraman, S., \& MacMillan, I. C. (1996). Innovation, competitive advantage, and rent. Management Science, 42(3), 389-403.

Ordonez de Pablos, P. (2002). Evidence of intellectual capital disclosure measurement from Asia, Eurpore and the Middle East. Journal of Intellectual Capital, $3(3), 287-302$.

Peteraf, M. (1993). The cornerstone of competitive advantage: A resource-based view. Strategic Management Journal, 14(3), 179-191.

Petty, R., \& Cuganesan, S. (2005). Voluntary disclosure of intellectual capital by Hong Kong Companies: Examining size, industry and growth effects over time. Australian Accounting Review, 15(2), 40-50.

Porter, M. (1980). Competitive strategy. New York: Free Press.

Sengupta, P. (1998). Corporate disclosure quality and the cost of debt. Accounting Review, 73(4), 459-474.

Shi, C. (2003). On the trade-off between the future benefits and riskiness of R\&D: A bondholders' perspective. Journal of Accounting \& Economics, 35(2), 227-254. 
Starovic, D., \& Marr, B. (2003). Understanding corporate value: Managing and reporting intellectual capital. London: Chartered Institute of Management Accountants.

Tang, J. (2008). The effects of firm size on knowledge management in electrical and electronic manufacturing firms. International Journal of Management, 25(2), 308-321.

Tasker, S. (1998). Bridging the information gap: Quarterly conference calls as a medium for voluntary disclosure. Review of Accounting Studies, 3(1/2), 137-167.

Vergauwen, P. G. M. C., \& Alem, F. J. C. (2005). Annual report IC disclosures in the Netherlands, France and Germany. Journal of Intellectual Capital, 6(1), 89-104.

Wiklund, J., \& Shepherd, D. (2003). Knowledge-based resources, entrepreneurial orientation, and the performance of small and medium-sized businesses. Strategic Management Journal, 24(13), 1307-1314.

Williams, S. M. (2001). Is intellectual capital performance and disclosure practices related? Journal of Intellectual Capital, 2(3), 192-203.

Wolk, H. I., Dodd, J. L., \& Rozycki, J. J. (2008). Accounting theory (7th ed.). Los Angeles: Sage Publications.

World Bank (2006). Where is the wealth of nations?: Measuring capital for the 21 st Century. Washington, D.C.: The World Bank. Retrieved June 15, 2009, from siteresources.worldbank.org/INTEEI/214578-1110886258964/20748034/All. pdf

Zhang, L., \& Ding, S. (2006). The effect of increased disclosure on cost of capital: Evidence from China. Review of Quantitative Finance \& Accounting, 27(4), 283-401.

\section{Biographical Sketches of Authors}

Blaise M. Sonnier, DBA, JD, CPA, is an Assistant Professor in the School of Accounting at Florida International University, Miami, Florida, and is Of Counsel with the law firm of Allen \& Gooch, Lafayette, Louisiana. He earned his Juris Doctorate from Louisiana State University, Baton Rouge, Louisiana, and his Doctorate of Business Administration from Grenoble School of Management, Grenoble, France.

Kerry D. Carson, $\mathrm{PhD}, \mathrm{SPHR}, \mathrm{CCP}$, GRP, is a management professor at the University of Louisiana at Lafayette where he serves as the director of the quality enhancement plan for accreditation. He received his doctorate from Louisiana State University in business administration. His research interests are in the areas of commitment, performance management, and international business. 
Paula Phillips Carson, PhD, SPHR, CCP, GRP, is a professor in the Moody College of Business at the University of Louisiana at Lafayette. She is also a special assistant to the provost on assessment and serves on the university's lead accreditation team. Professor Carson received her doctorate from Louisiana State University in management. Her research and teaching interests include nonprofits and compensation. 